\title{
RECONSIDERING THE USE OF CUT-OFF SCORES: DCDQ - BRAZIL
}

\author{
RECONSIDERANDO O USO DOS PONTOS DE CORTE:DCDQ - BRASIL
}

Original Article

RECONSIDERANDO EL USO DE LOS PUNTOS DECORTE:DCDQ - BRASIL

Luciana Ferreira

(Physical Education Professional)

Carl Gabbard²

(Physical Education Professional)

José Luiz Lopes Vieira ${ }^{3}$

(Physical Education Professional)

Pâmela Norraila da Silva'

(Physical Education Professional)

Francielle Cheuczuk ${ }^{1}$

(Physical Education Professional)

Francielli Ferreira da Rocha'

(Physical Education Professional)

Vânia de Fátima Matias de Souza (Physical Education Professional)

Priscila Caçola ${ }^{4}$

(Physical Education Professional)

1. Universidade Estadual de Maringá (UEM), Maringá, PR, Brazil. 2. Texas A\&M University, College

Station-TX, USA.

3. Universidad Católica del Maule, Talca, Chile.

4. University of Texas, Arlington, TX, USA.

\section{Correspondence:}

Luciana Ferreira.

Av. Londrina, 934, Zona 8, Maringá,

PR, Brazil. 87050-730.

luferreira.ed@gmail.com

\begin{abstract}
Introduction: The DCDQ is a parental report designed to assess daily living activities of children, and serves as a useful questionnaire to aid in the diagnostic criteria of Developmental Coordination Disorder (DCD). It is divided into three components: control during movement, fine motor/handwriting, and general coordination. The results categorize children in two groups: "Indication of DCD/suspect DCD", and "probably not DCD". Objective: The objective of this study was to determine appropriate cut-off scores for the Developmental Coordination Disorder Questionnaire - Brazil (DCDQ-BR) for use with Brazilian children employing a large sample. Methods: Seven hundred and seven children ages 6-10 were assessed with the DCDQ-BR and the Bruininks-Oseretsky Test of Motor Proficiency (BOT-2). Descriptive statistics was used to characterize the sample, and concurrent validity was assessed using Pearson's Correlation Coefficient. Predictive validity was determined through values of sensitivity (S) and specificity (E), while ROC curves were used to determine the optimal cut-off score for the DCDQ-BR. Results: Pearson's correlation coefficient analysis revealed a significant correlation between total scores of the DCDQ-BR and BOT-2 $\left(r=0.55(p=0.00)\right.$. Cut-off scores for the DCDQ-BR based on the BOT-2 $17^{\text {th }}$ percentile (relating to below average descriptive category) were established as $\leq 40, \leq 46$ and $\leq 51$ for ages $6-7$ years and 11 months; 8-9 years and 11 months; and 10-10 years and 11 months, respectively. Conclusion: Based on the results of this study and previous literature suggesting the need for a reevaluation of cut-off scores for the Brazilian population with a larger sample, we recommend that the cut-off scores of the DCDQ-BR are adjusted to the values found with our sample. Level of evidence Il; Diagnostic studies - Investigating a diagnostic test.
\end{abstract}

Keywords: Motor Skills Disorders; Motor Skills; Child; Child Development.

\section{RESUMO}

Introdução: O DCDQ é um relatório para pais elaborado para avaliar as atividades diárias das crianças, além de servir como um questionário útil para auxiliar nos critérios diagnósticos de Transtorno do Desenvolvimento da Coordenação (TDC). O questionário é dividido em três componentes: controle durante o movimento, motricidade fina/escrita e coordenação geral. Os resultados classificam as crianças em dois grupos: "Indicação ou suspeita de TDC" e "provável não TDC". Objetivo: O objetivo do presente estudo consistia em determinar as pontuações de corte adequadas para o Questionário de Transtorno do Desenvolvimento da Coordenação - Brasil (DCDQ-BR) para uso com crianças brasileiras utilizando uma grande amostra. Métodos: Setecentas e sete crianças de seis a 10 anos foram avaliadas com o DCDQ-BR e o Teste de Proficiência Motora Bruininks-Oseretsky (BOT-2). Utilizaram-se estatísticas descritivas para caracterizar a amostra e a validade concorrente foi avaliada através do índice de Correlação de Pearson. A validade preditiva foi determinada através dos valores de sensibilidade (S), especificidade (E) e as curvas ROC foram realizadas para determinar o ponto de corte ótimo do DCDQ-BR. Resultados: A análise de correlação de Pearson revelou um a correlação significativa entre os escores totais do DCDQ-BR e BOT-2 $(r=0,55, p=0,00)$. Os pontos de corte para o DCDQ-BR com base no BOT-2 no 170 percentil (referentes a categoria descritiva abaixo da média) foram estabelecidos como $\leq 40, \leq 46$ e $\leq 51$ para seis anos a sete anos e 11 meses, oito anos a nove anos e 11 meses, e 10 anos a 10 anos e 11 meses, respectivamente. Conclusão: Com base nos resultados desse estudo e na literatura anterior sugerindo a necessidade de uma reavaliação das pontuações de corte para a população brasileira com uma amostra maior, recomendamos que as pontuações de corte do DCDQ-BR sejam ajustadas aos valores encontrados em nossa amostra. Nível de evidência ll; Estudos diagnósticos - Investigação de um exame para diagnóstico.

Descritores: Transtornos das Habilidades Motoras; Habilidades Motoras; Criança; Desenvolvimento Infantil.

\section{RESUMEN}

Introducción: El DCDQ es un informe para padres elaborado para evaluar las actividades diarias de los niños, además de servir como un cuestionario útil para ayudar en los criterios diagnósticos del Trastorno del Desarrollo de la Coordinación (TDC). El cuestionario se divide en tres componentes: control durante el movimiento, motricidad final escrita y coordinación general. Los resultados clasifican a los niños en dos grupos: "Indicación o sospecha de TDC" y "probable no TDC". Objetivo: El objetivo del presente estudio fue determinar las puntuaciones de corte adecuadas para el Cuestionario de Trastorno del Desarrollo de la Coordinación-Brasil (DCDQ-BR) para el uso con niños brasileños usando una gran muestra. Métodos: Setecientos y sieteniños de 6 a 10 años fueron evaluados con el DCDQ-BRy el Test de Destreza Motora Bruininks-Oseretsky (BOT-2). Se utilizaron estadísticas descriptivas para caracterizar la muestray la 
validez concurrente fue evaluada a través del indice de Correlación de Pearson. La validez predictiva fue determinada a través de los valores de sensibilidad (S), especificidad (E) y las curvas $R O C$ se realizaron para determinar el punto de corte óptimo del DCDQ-BR. Resultados: El análisis de correlación de Pearson reveló una correlación significativa entre las puntuaciones totales del DCDQ-BR y BOT-2 $(r=0,55, p=0,00)$. Los puntos de corte para el DCDQ-BR con base en el BOT-2 en el percentil 170 (referentes a la categoría descriptiva por debajo del promedio) se establecieron como $\leq 40, \leq 46$ y $\leq 51$ para seis a siete años y 11 meses, ocho años a nueve años y 11 meses, y 10 años a 10 años y 11 meses, respectivamente. Conclusión: Con base en los resultados de este estudio y en la literatura anterior sugiriendo la necesidad de una reevaluación de las puntuaciones de corte para la población brasileña con una muestra mayor, recomendamos que las puntuaciones de corte del DCDQ-BR sean ajustadas a los valores encontrados con nuestra muestra. Nivel de evidencia ll; Estudios diagnósticos - Investigación de un examen para diagnóstico.

Descriptores: Trastornos de la Destreza Motora; Habilidades motoras; Niño; Desarrollo Infantil.

\section{INTRODUCTION}

Developmental coordination disorder (DCD) is considered a legitimate clinical condition and an emerging research field in the international literature. Consequently, assessment results and accurate diagnoses have been studied in recent years. ${ }^{1,2}$ Currently, the term DCD is well known and commonly used in the field of learning difficulties in childhood and throughout life. DCD has been considered a major health problem among school-aged children worldwide, ${ }^{3,4}$ resulting in significantly negative effects on their ability to fully participate in daily activities at home and in school or in playing games. ${ }^{5}$

Motor assessment is one of the criteria stablished by the Diagnostic and Statistical Manual of Mental Disorders (DSM-5) for DCD diagnosis. ${ }^{6}$ Common assessment instruments include the Movement Assessment Battery for Children (MABC-2) ${ }^{7}$ and the Bruininks-Oseretsky Test of Motor Proficiency, second edition (BOT-2). ${ }^{8}$ In addition to a broad assessment scope that includes 53 tasks, the BOT-2 provides an overview of the child's motor skills, being one of the most widely used assessment tools. ${ }^{9,10}$ Although these tests have been used by professionals as part of a broader assessment to identify DCD, parental questionnaires have been reported as important initial screening tools. ${ }^{4,11}$

The revised Developmental Coordination Disorder Questionnaire (DCDQ-R) ${ }^{11}$ is one of the most widely used assessment tools. ${ }^{12}$ It was developed in Canada using a sample of 287 children ${ }^{11}$ to screen and identify DCD. ${ }^{11,13}$ Some studies reported that this questionnaire is a valuable screening tool for collecting parental information ${ }^{14}$ and a valid instrument to confirm the indications of a possible or suspected for DCD. ${ }^{15-17}$ Parental responses were found to be associated with MABC-2 $(r=0.59)$ and BOT-2 $(r=0.46)$ scores, showing a close relationship with DCDQ. ${ }^{18}$

When used as a parent-response questionnaire, the DCDQ enables a qualitative and precise assessment of the child's motor skills. ${ }^{18}$ This instrument includes three general motor behavior categories: control during movement, fine motor skills/handwriting, and general coordination. Individual scores were added to obtain the total score, ranging from 15 to 75; higher scores indicate better motor skills. These scores are used to classify children into the following categories: "indication of possible DCD or suspected for DCD" and "probably not DCD."The DCDQ-R was designed for children aged 5-15 years, with different cutoff scores recommended for the three age groups.

This instrument is not expensive and less time consuming compared with a practical assessment. Its popularity can be confirmed by multiple translations and adaptations in several countries including Australia, ${ }_{1}^{17}$ Italy, ${ }_{1}^{19}$ Taiwan, ${ }^{20}$ France, ${ }^{21}$ and India. ${ }^{22}$ In Brazil, the DCDQ-R was cross-culturally validated by Prado et al. ${ }^{23}$ who analyzed 45 children, and was highly considered as a potential DCD screening tool. However, more data should be obtained in order to accurately determine the cutoff scores for the Brazilian population. This issue was addressed in other studies, which recommended that the use of original cutoff scores should be reconsidered $19,20,22$ depending on the clinical objectives. For example, Patel and Gabbard 22 used the recommended cutoff scores and concluded that $51 \%$ of their sample were at risk for DCD; however, after using more strict cutoff scores ( $\leq 31$, 35 , and 36 [for the three age groups]), this prevalence was reduced to $7 \%$.

These results show an urgent need to re-examine the current DCDQ-BR cutoff indices to determine more accurate cutoff values in order to identify children with indication of possible DCD or suspected for DCD. Considering the information above, this study aimed to determine the DCDQ-BR cutoff scores for the Brazilian population using a representative $n$ sample $(n=707)$ and based on DCDQ-BR responses and BOT-2 scores.

\section{METHODS}

\section{Participants}

A total of 707 children (332 boys, 375 girls) aged 6-10 years participated in the study. The mean age was $8.21 \pm 1.25$ years for girls and $8.24 \pm 1.18$ years for boys. Parents reported that their children had no known conditions associated with mental or physical disabilities. The sample included children with different socioeconomic status (SES) based on the parents' educational level and family income. All ethical-related procedures included in this study were approved by the Institutional Research Council of the University (opinion no.: 1,207,141/2015).

The children were divided by age group using the classification reported by Wilson et al. ${ }^{11}: 6-7$ years and 11 months ( $\left.n=206\right), 8-9$ years and 11 months $(n=352)$, and 10-10 years and 11 months $(n=149)$.

\section{Instruments}

The BOT- $2^{8}$ was used to assess fine and gross motor skills in four areas: fine manual control, manual coordination, body coordination, and strength and agility. During the test, motor skills were classified as "well-above average," "above average," "average," "below average," or "well-below average."

Parental opinions on motor skills were collected using the DCDQ-BR. ${ }^{23}$ This 15-item questionnaire has three subscales: control during movement, fine motor skills/handwriting, and general coordination. The maximum score after adding the three areas is 75; higher scores indicate better motor skills.23

\section{PROCEDURES}

The parents signed an informed consent form, and the children gave a verbal consent to participate in this study before data collection. One of the parents or legal guardians completed the DCDQ-BR.

\section{Statistical analysis}

The statistical package SPSS version 22.0 was used to calculate the descriptive statistics, mean-standard deviation, and minimum-maximum values. The Pearson's correlation between BOT-2 and DCDQ-BR percentiles was used to calculate concurrent validity. 
Predictive validity, sensitivity (S), and specificity (SP) were calculated according to the criteria proposed by Portney and Watkins, ${ }^{24}$ where $S$ is the probability of obtaining a correct positive result in children suspected for DCD, and SP is the probability of a correct negative result in children not suspected for DCD. These values were calculated using DCDQ scores based on percentiles 2 and 17 (BOT-2) to determine which cutoff score has the best potential to predict DCD. Percentiles 2 and 17 were used because they represented the stipulated classifications (well-below average and below average) to assess motor skills. Finally, the cutoff score was estimated using the receiver operating characteristic curve (ROC curve), with a statistical significance level of $5 \%$. The ROC curve was constructed using the MedCalc software.

\section{RESULTS}

Table 1 presents the mean, standard deviation, and minimum-maximum values of DCDQ-BR subscales. The minimum DCDQ-BR scores achieved by children aged 6-7 years and 11 months were 25 points for boys and 29 points for girls. Children aged 8-9 years and 11 months garnered 31 points for boys and 26 points for girls. Children aged 10-10 years and 11 months garnered 31 points for both boys and girls. There were no significant differences between sexes.

Considering the BOT-2 percentile 2, the most rigorous reference standard, the incidence of suspected DCD was $1.5 \%(n=3)$ in children 6-7 years and 11 months, 1.1\% $(n=4)$ in children aged $8-9$ years and 11 months, and $2 \%(n=3)$ in children aged $10-10$ years and 11 months. However, considering BOT-2 percentile 17, the incidence of DCD was $15.4 \%(n=36)$ in children aged $6-7$ years and 11 months, $21.6 \%$ $(n=76)$ in children aged 8-9 years and 11 months, and 36.9\% $(n=55)$ in children aged 10-10 years and 11 months (Table 2).

Pearson's correlation coefficients (Table 3 ) indicated positive, moderate, and significant relationships among all BOT-2 and DCDQ-BR subtest percentiles. Correlation coefficients ranged from 0.25 to 0.55 . The results were similar for DCDQ-BR and BOT-2 relationships by age groups. The relationship between total BOT-2 and total DCDQ-D (DCDQ-BR) was moderate $(r=.55$ for $p<0.01)$.

Table 4 presents the S, SP, area of the curve, and cutoff scores for DCDQ-BR and subscales, considering BOT-2 percentiles 2 and 17. According to the ROC curves and considering percentile 2 (the most restricted), the cutoff scores for total DCDQ-BR from 6-7 years and 11 months, 8-9 years and 11 months, and 10-10 years and 11 months were $\leq 45, \leq 39$, and $\leq 35$ points, respectively. When considering percentile 17 , the most appropriate cutoff scores for total DCDQ-BR in children 6-7 years and 11 months, 8-9 years and 11 months, and 10-10 years and 11 months were $\leq 51, \leq 46$, and $\leq 40$ points, respectively.
Table 1. Descriptive statistics (mean, standard deviation, and minimum-maximum values) for total DCDQ and subscales by age group and sex.

\begin{tabular}{|c|c|c|c|c|c|c|}
\hline & \multicolumn{2}{|c|}{$\begin{array}{l}6-7 \text { years and } 1 \\
\text { month }(n=206)\end{array}$} & \multicolumn{2}{|c|}{$\begin{array}{l}8-9 \text { years and } 11 \\
\text { months }(n=352)\end{array}$} & \multicolumn{2}{|c|}{$\begin{array}{l}10-10 \text { years } \\
\text { and } 11 \text { months } \\
(n=149)\end{array}$} \\
\hline & Boys & Girls & Boys & Girls & Boys & Girls \\
\hline$N$ & 87 & 119 & 186 & 166 & 59 & 90 \\
\hline \multicolumn{7}{|l|}{ Total DCDQ } \\
\hline Mean & 58.75 & 56.92 & 60.13 & 58.08 & 56.32 & 57.26 \\
\hline Standard deviation & 11.30 & 12.51 & 11.09 & 12.77 & 13.38 & 13.36 \\
\hline Min-max & $25-75$ & $29-75$ & $31-75$ & $26-75$ & $31-75$ & $31-75$ \\
\hline \multicolumn{7}{|l|}{ CDM } \\
\hline Mean & 23.69 & 22.45 & 24.55 & 22.73 & 22.20 & 22.37 \\
\hline Standard deviation & 5.28 & 5.80 & 4.99 & 5.88 & 6.12 & 6.22 \\
\hline Min-max & $10-30$ & $8-30$ & $8-30$ & $8-30$ & $9-30$ & $8-30$ \\
\hline \multicolumn{7}{|l|}{$\mathrm{FH}$} \\
\hline Mean & 15.29 & 15.06 & 15.49 & 15.66 & 15.05 & 15.73 \\
\hline Standard deviation & 3.58 & 3.46 & 3.67 & 3.79 & 4.07 & 3.88 \\
\hline Min-max & $6-20$ & $6-20$ & $5-20$ & $5-20$ & $6-20$ & $4-20$ \\
\hline \multicolumn{7}{|l|}{$\mathrm{GC}$} \\
\hline Mean & 19.77 & 19.42 & 20.10 & 19.69 & 19.07 & 19.16 \\
\hline Standard deviation & 4.22 & 4.35 & 4.09 & 4.29 & 4.62 & 4.62 \\
\hline Min-max & $8-25$ & $9-25$ & $6-25$ & $9-25$ & $11-25$ & $7-25$ \\
\hline
\end{tabular}

Total DCDQ = total Developmental Coordination Disorder Questionnaire score, $C D M=$ control during movement, $\mathrm{FH}=$ fine motor skills/handwriting, $\mathrm{GC}=$ general coordination

Table 2. Percentage of children with indication of or suspected for DCD according to the DCDQ-R manual and cutoff scores recommended in this study.

\begin{tabular}{c|c|c}
\hline Age & $\begin{array}{c}\text { DCDQ-R cutoff } \\
\text { scores }\end{array}$ & $\begin{array}{c}\text { Cutoff scores recommended } \\
\text { for Brazil }\end{array}$ \\
\hline 5-7 years and 11 months & $18.9(41)$ & $15.4(36)$ \\
\hline 8-9 years and 11 months & $29.8(105)$ & $21.6(76)$ \\
\hline 10-15 years & $39.9(59)$ & $36.9(55)$ \\
\hline
\end{tabular}

$\mathrm{DCDQ}=$ Developmental Coordination Disorder Questionnaire - revised.

Table 3. Correlation between DCDQ-BR and BOT-2 results.

\begin{tabular}{c|c|c|c|c}
\hline $\mathbf{n}=\mathbf{7 0 7}$ & $\begin{array}{c}\text { Control } \\
\text { during } \\
\text { movement }\end{array}$ & $\begin{array}{c}\text { Fine motor } \\
\text { skills/ } \\
\text { handwriting }\end{array}$ & $\begin{array}{c}\text { General } \\
\text { coordination }\end{array}$ & $\begin{array}{c}\text { Total } \\
\text { DCDQ }\end{array}$ \\
\hline Fine manual control & $0.32^{*}$ & $0.26^{*}$ & $0.25^{*}$ & $0.32^{*}$ \\
\hline Manual coordination & $0.43^{*}$ & $0.35^{*}$ & $0.42^{*}$ & $0.45^{*}$ \\
\hline Body coordination & $0.37^{*}$ & $0.36^{*}$ & $0.37^{*}$ & $0.41^{*}$ \\
\hline Strength and agility & $0.41^{*}$ & $0.31^{*}$ & $0.38^{*}$ & $0.42^{*}$ \\
\hline Total BOT-2 & $0.53^{*}$ & $0.44^{*}$ & $0.49^{*}$ & $0.55^{*}$ \\
\hline
\end{tabular}

Pearson, ${ }^{*} \mathrm{p}<0.01$. BOT-2 = Bruininks-Oseretsky Test of Motor Proficiency Second Edition, DCDQ = Developmenta Coordination Disorder Questionnaire, DCDQ-BR = Developmental Coordination Disorder Questionnaire - Brazil.

Table 4. Sensitivity, specificity, curve area, and cutoff scores for total DCDQ and subscales considering the BOT-2 percentile 2 and 17 reference values.

\begin{tabular}{|c|c|c|c|c|c|c|c|c|c|c|c|c|c|}
\hline & \multirow[t]{2}{*}{$\begin{array}{c}\% \\
\text { BOT-2 }\end{array}$} & \multicolumn{4}{|c|}{ 6-7 years and 11 months } & \multicolumn{4}{|c|}{$8-9$ years and 11 months } & \multicolumn{4}{|c|}{$10-10$ years and 11 months } \\
\hline & & $S$ & SP & Curve area & ROC & $S$ & SP & Curve area & ROC & $S$ & SP & Curve area & ROC \\
\hline Total DCDQ & $17 \%$ & 75.0 & 87.0 & 0.841 & $\leq 40$ & 61.8 & 93.8 & 0.774 & $\leq 46$ & 54.5 & 96.8 & 0.824 & $\leq 51$ \\
\hline CDM & $2 \%$ & 100.0 & 60.6 & 0.783 & $\leq 22$ & 100.0 & 93.4 & 0.965 & $\leq 14$ & 100.0 & 87.0 & 0.950 & $\leq 14$ \\
\hline $\mathrm{FH}$ & $17 \%$ & 68.2 & 84.0 & 0.814 & $\leq 13$ & 63.2 & 84.4 & 0.725 & $\leq 13$ & 65.5 & 78.7 & 0.769 & $\leq 14$ \\
\hline \multirow{2}{*}{ GC } & $2 \%$ & 100.0 & 74.9 & 0.837 & $\leq 16$ & 100.0 & 79.9 & 0.934 & $\leq 16$ & 100.0 & 75.3 & 0.869 & $\leq 15$ \\
\hline & $17 \%$ & 59.1 & 91.4 & 0.799 & $\leq 15$ & 68.4 & 80.4 & 0.786 & $\leq 18$ & 58.2 & 92.6 & 0.894 & $\leq 15$ \\
\hline
\end{tabular}

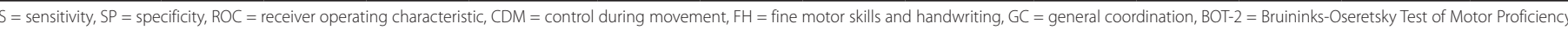
Second Edition. 


\section{DISCUSSION}

The present study evaluated the motor skills of 707 children aged 6-10 years to determine the cutoff scores recommended by the Developmental Coordination Disorder Questionnaire for the Brazilian population using the BOT-2 as reference standard. Correlations and good sensitivity and specificity adjustments were found among all DCDQ-BR subscales and the BOT-2, which allowed us to reconsider DCDQ-BR cutoff scores. The cutoff scores that indicates suspected DCD stipulated by the DCDQ- $\mathrm{R}^{11}$ manual are $\leq 46$ for children aged $5-7$ years and 11 months, $\leq 55$ for children aged 8-9 years and 11 months, and $\leq 57$ for children aged $10-15$ years.

The cutoff scores stipulated by this study are $\leq 51$ for children aged 6-7 years and 11 months, $\leq 46$ for children aged $8-9$ years and 11 months, and $\leq 40$ for children aged 10-10 years and 11 months.

The correlation between total DCDQ-BR score and BOT-2 values was considered moderate and positive $(r=.55)$, which is similar to the values described by Wilson et al. ${ }^{13}$ for correlations between MABC and DCDQ $(r=.47)$ and BOT-2 subtests and DCDQ $(r=.57)$. Although motor skill problems can also influence a child's performance of activities of daily living, ${ }_{1}^{16}$ BOT-2 and DCDQ measure different aspects of motor behavior. The BOT-2 measures a series of very specific motor skills, while the DCDQ considers functional motor coordination manifestations in daily activities. Therefore, sensitivity is particularly important, as it reflects the parents ability to use DCDQ to correctly identify children with DCD. In our study, the desired sensitivity rate was achieved, demonstrating that 75\% (for the 6-to-7-year-old groups, for example) of children suspected for DCD were correctly identified using the DCDQ-BR.

The assessment based on the cutoff scores suggested in the DCDQ-R manual ${ }^{11}$ resulted in a relatively high rate of children with indication of or suspected for DCD (percentage ranged from 18.9\% to 39.9\% in the groups). However, when considering the BOT-2 percentile 17 (below-average motor skills), the number of children with indication of or suspected for DCD was $15.4 \%$ in the group aged 6-7 years and 11 months, 21.6\% in the group aged 8-9 years and 11 months, and $36.9 \%$ in the group aged 10-10 years and 11 months. These results are relatively higher than those reported in Australia ${ }^{17}$ (30\%) and Greece ${ }^{25}$ (19\%), but lower than the number of children with indication of or suspected for DCD when considering the cutoff scores established for the Canadian population ${ }^{11}$ (Table 5). Patel and Gabbard ${ }^{22}$ found a similar mean of 7\% for children suspected for DCD, but the use of cutoff scores established by Wilson ${ }^{11}$ resulted in a mean of $51 \%$ for children suspected for DCD. Interestingly, using stricter cutoff scores for BOT-2 percentile 2, 1.1\%-2\% of children were suspected of having DCD. A similar discrepancy was reported by Caravale et al., ${ }^{26}$ who used the MABC-2 percentile 5 instead of 15, with $5.5 \%$ and $19.3 \%$ of children suspected for DCD, respectively.

These results are justified by documented differences between motor standards for Brazilian and North American children. Several studies explained that Brazilian children tend to present motor skills below the level found in North American and Canadian children. This difference was detected from the first months of life in a study by Santos, Gabbard, and Gonçalves, ${ }^{27}$ who analyzed developmental standards in babies and reported that the Brazilian sample presented significantly lower mean values. Valentini et al. ${ }^{28}$ reported that $24.1 \%$ of Brazilian children aged four to 12 years were suspected for DCD, which is in contrast with that reported in North American children (10.1\%). As evidence indicates that Brazilian children have lower motor standards, it is necessary to reanalyze, reconsider, and adapt cutoff scores based on these findings.

Another factor that may have contributed to the moderate values found in this study is the fact that BOT-2 has not been validated for Brazilian children, and this one of the limitations of the study; however, this instrument was chosen to comprehensively assess motor skills and as this was used as a reference standard in other concurrent validity studies. ${ }^{18}$ In addition, our sample included children aged 6-10 years and did not include older children aged 11-14 years, which is contrary to the reports of the original study. ${ }^{11}$ We believe that the benefits of this study may outweigh its limitations, since this study analyzed the relationship between motor skills and parental motor skill reports using a large sample $(n=707)$ and presented specific cutoff scores for Brazilian children.

Future studies should analyze a stratified sample due to the large Brazilian territorial scope, aiming at broader and more generalized results. Other motor tests such as Movement Assessment Battery for Children - Movement-ABC, Körper-Koordinationtest für Kinder, and Test of Gross Motor Development should be used, in addition to the inclusion of children previously identified with DCD in the sample.

\section{CONCLUSION}

The data support the use of the total DCDQ-BR score for screening children with indication of possible or suspected for DCD in the Brazilian population. It was evident that the use of different DCDQ cutoff scores or criteria for diagnosis resulted in a variable number of correctly identified children indicated of or suspected for DCD, according to the analyzed percentiles. Therefore, we conclude that parental assessment using the DCDQ-BR is significantly associated with real motor skills. We recommend that cutoff scores should be reconsidered and adapted to classify the DCDQ-BR for the Brazilian population.

\section{ACKNOWLEDGMENTS}

We thank CAPES for the doctoral fellowship grant and for the Sandwich PhD provided for Luciana Ferreira.

All authors declare no potential conflict of interest related to this article

AUTHORS' CONTRIBUTIONS: Each author made significant individual contributions to this manuscript. LF (0000-0001-5808-2334)*: responsible for the entire preparation of the article, writing of the article, statistical analysis, review and collection of data; CG (0000-0003-2841-5833)* contributed to the intellectual concept of the study, writing and review; JLLV (0000-0003-0453-8185)*: writing of the manuscript, review and creation of the entire research project; PNS (0000-0001-7277-6084)*: participated in the definition of methods, collaboration in the discussion of results and collection of data; FC (0000-0003-2391-7332)*: writing of the article and collection of data; FFR (0000-0001-7866-6070)*: writing of the manuscript, review, creation of the entire research project and collection of data; VFMS: (0000-0003-4631-1245)*: participated in the definition of methods, collaboration in the discussion of results and collection of data; PC (0000-0003-2713-5733)*: performed the review and final approval of the manuscript. All authors approved the final version of the manuscript. *ORCID (Open Researcher and Contributor ID).

\section{REFERENCES}

1. Caçola P, Miller, HL, Williamson PO. Behavioral comparisons in autism spectrum disorder and developmental coordination disorder: a systematic literature review. Res Autism Spectr Disord. 2017;38:6-18.

2. King-Dowling S, Rodriguez MC, Missiuna C, Cairney J.Validity of the ages and stages questionnaire to detect risk of developmental coordination disorder in preschoolers. Child Care Health Dev. 2016;42(2):188-94.
3. Cairney J,Veldhuizen S, Szatmari P. Motor coordination and emotional-behavioral problems in children. Curr Opin Psychiatry. 2010;23(4):324-9.

4. Green D, Bishop T, Wilson BN, Crawford S, Hooper R, Kaplan B, et al. Is Questionnaire-Based screening part of the solution to waiting lists for children with developmental coordination disorder? Br J Occup Ther. 2005;68(1):2-10. 
5. Caçola P. Movement difficulties affect children's learning: an overview of developmental coordination disorder (DCD). Learn Disabil. 2014;20(2):98-106.

6. American Psychiatric Association. Diagnostic and statistical manual of mental disorders. 5th. ed. Arlington, VA: American Psychiatric Association; 2013

7. Henderson SE, Sudgen DA, Barnett AE. Movement assessment battery for children. 2nd ed. (Movement ABC-2). London, UK: Pearson Assessment; 2007.

8. Bruininks R, Bruininks B. Bruininks-Oseretsky test of motor proficiency. 2nd ed. Circle Pines, MN: AGS Publishing; 2005

9. Lane $\mathrm{H}$, Brown T. Convergent validity of two motor skill tests used to assess school-age children. Scand J Occup Ther. 2015;22(3):161-72.

10. Wuang Y, Lin Y, Su C. Rasch analysis of the Bruininks-Oseretsky test of motor proficiency-second edition in intellectual disabilities. Res Dev Disabil. 2009;30(6):1132-44.

11. Wilson BN, Crawford SG, Green D, Roberts G, Aylott A, Kaplan BJ. Psychometric properties of the revised developmental coordination disorder questionnaire. Phys Occup Ther Pediatr. 2009;29(2):182-202.

12. Kennedy-Behr A, Wilson BN, Rodger S, Mickan S. Cross-cultural adaptation of the developmental coordination disorder questionnaire 2007 for German-speaking countries: DCDQ-G. Neuropediatrics. 2013;44(5):245-51.

13. Wilson BN, Kaplan BJ, Crawford SG, Campbell A, Dewey D. Reliability and validity of a parent questionnaire on childhood motor skills. Am J Occup Ther. 2000;54(5):484-93.

14. Brown T, Lane H. Comparing a parent-report and a performance-based measure of children's motor skill abilities: are they associated? Occup Ther Health Care. 2014;28(4):371-81.

15. Rivard L, Missiuna C, McCauley D, Cairney J. Descriptive and factor analysis of the developmental coordination disorder questionnaire (DCDQ'07) in a population-based sample of children with and without developmental coordination disorder. Child Care Health Dev. 2014;40(1):42-9.

16. Schoemaker MM, Flapper B, Verheij NP, Wilson BN, Reinders-Messelink HA, de Kloet A. Evaluation of the developmental coordination disorder questionnaire (DCDQ) as a screening instrument. Dev Med Child Neurol. 2006:48(8):668-73.
17. 17. Civetta LR. The developmental coordination disorder questionnaire and movement assessment battery for children as a diagnostic method in Australian children. Pediatr Phys Ther. 2008;20(1):39-46.

18. Crawford SG, Wilson BW, Dewey D. Identifying developmental coordination disorder: consistency between tests. Phys Occup Ther Pediatr. 2001;20(2-3):29-50.

19. Caravale B, Baldi S, Gasparini C, Wilson BN. Cross-cultural adaptation, reliability and predictive validity of the Italian version of developmental coordination disorder questionnaire (DCDQ). Eur J Paediat Neurol. 2014;18(3):267-72.

20. Tseng MH, Fu CP, Wilson BN, Hu FC. Psychometric properties of a chinese version of the developmental coordination disorder questionnaire in community-based children. Res Dev Disabil. 2010;31(1):33-45.

21. Martini R, St-Pierre MF, Wilson BN. French Canadian cross-cultural adaptation of the Developmental Coordination Disorder Questionnaire'07: DCDQ-FC. Can J Occup Ther. 2011;78(5):318-27.

22. Patel P, Gabbard C. Adaptation and preliminary testing of the developmental coordination disorder questionnaire (DCDQ) for children in India. Phys Occup Ther Pediatr; 2017;37(2):170-82.

23. Prado MS, Magalhães LC, Wilson BN. Cross-cultural adaptation of the developmental coordination disorder questionnaire for Brazilian children. Braz J Phys Ther. 2009;13(3):236-43.

24. Portney LG, Watkins MP. Foundations of clinical research: applications to practice. 3nd ed. Upper Saddle River: Pearson Prentice Hall; 2009.

25. Tsiotra GD, Flouris AD, Koutedakis Y, Faught BE, Nevill AM, Lane AM, et al. A comparison of developmenta coordination disorder prevalence rates in Canadian and Greek children. J Adolesc Health. 2006;39(1):125-7.

26. Caravale C, Baldi S, Capone L, Presaghi F, Balottin U, Zoppello M. Psychometric properties of the Italian version of the developmental coordination disorder questionnaire (DCDQ-Italian). Res Dev Disabil. 2015;36C:543-50.

27. Santos DC, Gabbard C, Goncalves VM. Motor development during the first year: a comparative study. J Genet Psychol. 2001;162(2):143-53.

28. Valentini NC, Oliveira MA, Pangelinan MM, Whitall J, Clark JE. Can the MABC discriminate and predict motor impairment? A comparison of Brazilian and American children. Int J Ther Rehabil. 2017;24(3):105-13 